\title{
Spatial differences of reindustrialization in a post-socialist economy: manufacturing in the Hungarian counties
}

\author{
Imre Lengyel, Zsofia Vas, Izabella Szakalne Kano \& Balazs Lengyel
}

To cite this article: Imre Lengyel, Zsofia Vas, Izabella Szakalne Kano \& Balazs Lengyel (2017) Spatial differences of reindustrialization in a post-socialist economy: manufacturing in the Hungarian counties, European Planning Studies, 25:8, 1416-1434, DOI: 10.1080/09654313.2017.1319467

To link to this article: http://dx.doi.org/10.1080/09654313.2017.1319467

\section{Published online: 27 Apr 2017.}

\section{Submit your article to this journal $\square$}

山 Article views: 62

Q View related articles ¿

View Crossmark data ¿ 


\title{
Spatial differences of reindustrialization in a post-socialist economy: manufacturing in the Hungarian counties
}

\author{
Imre Lengyel $^{\mathrm{a}}$, Zsofia Vas ${ }^{\mathrm{a}}$, Izabella Szakalne Kano ${ }^{\mathrm{a}}$ and Balazs Lengyel ${ }^{\mathrm{b}}$ \\ ${ }^{\mathrm{a}}$ Faculty of Economics and Business Administration, University of Szeged, Szeged, Hungary; ${ }^{\mathrm{b}}$ Centre for \\ Economic and Regional Studies, Hungarian Academy of Sciences, Budapest, Hungary
}

\begin{abstract}
Over the past two and a half decades, the post-socialist countries of Central and Eastern Europe, including Hungary, have become an integral part of the global economy. Following the change of regime, the rate of foreign direct investment increased, modern industries emerged and exports became significant. However, this process was halted by the global economic crisis in many advanced and transition economies, and the concept of 'reindustrialization' emerged as one of the economic policy responses to the new challenges generated by the crisis. In our paper, we study whether reindustrialization is present following the lowest point of the crisis in one of the post-socialist countries of the EU, in Hungary. If so, in which regions and industries, and under what conditions? Our research indicates that reindustrialization can be generally observed only in a few rural regions after 2009, limited to only one or two industries, while, for instance, in the capital and in its agglomerations and in urban regions with large research universities, deindustrialization is more likely to take place.
\end{abstract}

\section{ARTICLE HISTORY}

Received 2 December 2016

Revised 20 March 2017

Accepted 10 April 2017

\section{KEYWORDS}

Reindustrialization; manufacturing; spatial differences; transition economy; Hungary

\section{Introduction}

The concept of reindustrialization appeared in the literature concerned with developed countries almost three decades ago (Barta, Czirfusz, \& Kukely, 2008; Etzioni, 1983; Krugman, 1988; Lower, 1982; Wink, Kirchner, Koch, \& Speda, 2015). In several economies, reindustrialization has arisen as an economic development idea and a vision of a new industrial policy as a response to the challenges resulting from the crisis of 2008 and its consequences. Many documents and resolutions in the $\mathrm{EU}$ and its member states have been formulated to promote it (Cimoli, Dosi, \& Stiglitz, 2015; Christopherson, Martin, Sunley, \& Tyler, 2014; European Commission [EC], 2014; Landesman, 2015; Lux, 2015; Tregenna, 2013; Westkamper, 2014). A significant part of the EU Structural and Investment Funds is marked out for new industrial and regional development paths, and, for example, the Communications on 'An Integrated Industrial Policy for the Globalization Era' (EC, 2010), and 'For a European Industrial Renaissance' (EC, 2014) foster industrial competitiveness. The latter proposes to achieve a share of $20 \%$ of manufacturing activities by 2020 instead of the former approximately $15 \%$. They primarily advocate the 
advancement of the 'knowledge-based economy', the enhancement of industrial activities with higher value added and the boosting of related business services (Westkamper, 2014). The term the '4th industrial revolution' has also emerged in connection with reindustrialization, which indicates that automated manufacturing activities are coordinated by 'unmanned' integrated computer networks (Porter \& Heppelman, 2015; Schwab, 2015).

The prerequisites and possibilities of reindustrialization in post-socialist countries are different from those of advanced economies. In order to promote reindustrialization, the Hungarian economic policy aims to increase the share of industry in gross domestic product from the current $26 \%$ to $30 \%$ by 2020 . Reindustrialization may occur in any industrial section (mining and quarrying, manufacturing, electricity, gas, steam and air conditioning supply, water supply, sewerage, waste management and remediation activities); however, the key sector is manufacturing in production and labour. In the postsocialist economies, the share of manufacturing in gross value added (GVA) is higher in every single year in the last decade than in the countries of the EU15. In 2014, in Hungary the share of manufacturing in GVA was $23.3 \%$, which is the third highest rate in the EU. The first three positions of the ranking are filled by three post-socialist transition economies (Czech Republic 26.8\%, Romania 23.7\%), while in EU28 (15.6\%) and in EU15 (15.2\%) manufacturing is of much less importance.

In Hungary, the rate of manufacturing employment is $18.4 \%$, which is the fifth in the EU, following the Czech Republic, Slovakia, Slovenia and Poland. It has also been shown that while the share of post-socialist countries in the GVA of EU manufacturing increased from $6.7 \%$ in 2006 to $8.7 \%$ in 2015, the share of EU15 in this period - even if it produces nearly $90 \%$ of the total manufacturing GVA - decreased by $2.4 \%$ (EU, 2015). These spatial differences and the process of industrialization in manufacturing are the subjects of the recent study, with a special focus on one of the post-socialist countries, Hungary.

Our paper examines whether reindustrialization is present in the context of manufacturing after the lowest point of the crisis, between 2009 and 2014 in Hungary, and if so, in which regions and industries. For this, first, we explore the phenomenon of reindustrialization, the spatial concentration of industries and the specialization of regions. Next, we present the national trends and spatial structure of manufacturing in Hungary, and then we describe the database and the methodological background that we used. Following that, we analyse the spatial concentration of 13 manufacturing subsections and the specialization of 19 counties on the NUTS-3 level of Hungary between 2009 and 2014 based on employment numbers and export sales, using entropy-based Theil indexes in both cases. At the end of the paper, we outline the region types of reindustrialization found in Hungary, and the spatial possibilities and limits of transitional post-socialist countries.

\section{Theoretical background}

Reindustrialization is a complex phenomenon that refers to both spontaneous economic processes and economic development efforts, and cannot be analyzed without understanding the notion of industrialization and deindustrialization. Industrialization refers to an economic structural change which is observable in the increase in the number of industrial employment or in the growth of the share of industry within GVA (Scott \& Storper, 1992; Szirmai, 2012; Weiss, 2002). The process of industrialization may occur in any segment of the economy producing goods and related services, and takes place in different ways at 
different times: it has been launched 50-150 years ago in developed countries, and has started few decades ago in developing economies.

From the second half of the twentieth century, developed countries have rather been characterized by deindustrialization, with services gaining an increased focus (Cairncross, 1982; Kudina \& Pitelis, 2014; Tregenna, 2009). The removal or reduction of industrial activities and capacity can be explained by several factors (Christopherson et al., 2014): by productivity improvement as a result of technological changes leading to reduction in the number of industrial employment, by the outsourcing of services to independent companies, by industrialization and modernization of developing countries, by the appearance of infocommunication services, etc.

Reindustrialization implies the emergence of new industries and industrial structural changes, as well as the growing productivity of existing traditional industries (Tregenna, 2013; Westkamper, 2014). However, in developed countries, for example, it is no longer about fostering or replacing industries characterized by mass production, limited technological capabilities and low wages, but about stimulating the development of the knowledge-based economy and boosting industries with higher added value, higher wages and highly qualified workforce.

Two aspects which strongly influence productivity in global competition become more important in terms of reindustrialization: one is the spatial concentration of industries, and the other is the specialization of regions (Fujita \& Thisse, 2002; Thissen, van Oort, Diodato, \& Ruijs, 2013). Both concentration and specialization can be interpreted in relation to the economic structure of a particular country, but reindustrialization is rather to be defined related to the structural change of the economy of subnational territorial units (regions, counties and city regions).

The economies resulting from spatial concentration were recognized by, among others, Alfred Marshall, proving the importance of local externalities generated by industrial districts (Ács \& Varga, 2002; Drucker, 2013; McCann, 2013). Today, these local externalities are (Fujita, Krugman, \& Venables, 1999) a large industrial market, specialized local labour markets and the spillover of industrial knowledge. In discussing the possibilities of reindustrialization, we cannot even disregard the three basic types of the so-called agglomeration economies resulting from the spatial concentration of the economy (Capello, 2015): (a) economies internal to the firm, also called economies of scale; (b) economies external to the firm but internal to the sector, or localization economies and (c) economies external to the firm and external to the sector, or urbanization economies. In addition, the new economic geography points out that spatial concentration is mainly influenced by lower unit transport costs, increasing economies of scale characterizing global, traded industries and monopolistic competition (Brakman, Garretsen, \& van Marrewijk, 2009; Combes, Mayer, \& Thisse, 2008; Fujita et al., 1999; Fujita \& Thisse, 2002).

The traditional approaches of regional economics concerned with the explanation of the concept of regional specialization, and relying on the theory of comparative advantages, categorize specialization basically into two groups (Johansson, 2000; Stimson, Stough, \& Roberts, 2006): scale-based and resource-based specialization. Today, many experts of regional studies emphasize the significance of absolute advantages, also known as competitive advantages, instead of comparative ones (Camagni, 2002; Capello, 2015). Porter (1990) defines three types of international (and regional) 
specialization based on competitive advantages, and distinguishes factor-driven, investment- or efficiency-driven and innovation-driven economies.

The establishment of the regional policy of the EU for the period of 2014-2020 also included the concept of smart specialization (EC, 2012; Foray, 2015; McCann, 2015; Organisation for Economic Co-operation and Development, 2013; Thissen et al., 2013). In order to promote the structural change of regions, this strategy proposes development programmes which rely on the competitive advantages of knowledge-intensive sectors, depend on the level of development and agglomeration economies of the regions, involve an entrepreneurial discovery process and are bottom-up and placebased (Seravalli, 2015). In terms of economic development possibilities, three ideal types of regions can be distinguished (EC, 2012): knowledge regions, industrial production zones, and not science and technology (not S\&T)-driven regions. In the latter two, reindustrialization may also emerge as a part of the development strategy. Similarly to competitive advantages, the regions are categorized as leaders, followers and less advanced regions.

The literature and international experience clearly show that the reindustrialization possibilities of regions greatly depend on the level of development of a particular region, the specialization of its economic structure, and the size and composition of its labour market. Consequently, different possibilities of reindustrialization may characterize the various types of regions.

\section{The manufacturing and its spatiality in Hungary}

In Hungary, 'socialist industrialization' took place in the period of 1949-1990: the proportion of industrial employees (including construction) was $21.6 \%$ in 1949, which increased to $34 \%$ in 1960 , and then to $43.7 \%$ in 1970 ; later it stagnated on this level until 1980 (Barta, 2002). Industry started to decline after the years of regime change, 1989: a part of large public companies were privatized or restructured, a part of them were closed down and, as a consequence, the number of industrial employees decreased by almost 300,000 from 1985 to 1995 (Barta et al., 2008). This indicates that the process of deindustrialization started after the change of regime, during which time manufacturing also declined.

From the mid-1990s, there was a turning point, and site locations of global companies have appeared in Hungary, and in the past decades, the Hungarian economy has been strongly integrated in global economy, particularly in the economy of the EU (Lorentzen, 1999). The Hungarian counties started to take different growth paths, and regional inequalities started to emerge mainly due to different geographical locations, infrastructural facilities, and the availability of qualified workforce and foreign direct investments (Kiss, 2007). Diverse spatial patterns of reindustrialization have begun to develop in Hungary. Industrial activities and services deconcentrated and new economic growth poles emerged in the countryside (Kovács \& Tosics, 2014). Furthermore, intensive local institutional and infrastructural developments have been completed, and new core regions appeared along the main transportation axes, decreasing the cultural and economic role of the capital, Budapest. Several subsections of manufacturing have become the key industries of the economy, and their spatial restructuring is substantial (Kiss, 2012; Lengyel, 2014; Lux, 2015; Nemes Nagy, 2000). 
After the turn of the millennium, but especially after the EU accession in 2004, production value, GVA, labour productivity (GVA per employee) and export sales of manufacturing dynamically increased up until 2007 in Hungary, while the number of employees (persons who are in employment in relationship and work at least 60 hours on monthly average) was continuously reduced (Figure 1). However, the growth of manufacturing came to a halt in 2008, mainly as a result of the global crisis, and sharply dropped in 2009. This was one of the reasons why the number of employees gradually decreased from 753,000 persons in 2000 to 650,000 persons in 2010 (by about 80,000 persons in 2008). Later it only slightly increased, to 665,000 persons in 2014.

In Hungary, manufacturing employees represented $27.7 \%$ of the nation in 2000 , which fell to $22.8 \%$ in 2009 and remained roughly constant until it slightly decreased in 2014 . Manufacturing GVA was $22.4 \%$ of the national value in 2000 , which decreased to $20.3 \%$ in 2009 with smaller fluctuations, and then gradually increased from this point, reaching $23.5 \%$ in 2014 . Labour productivity gradually decreased after a recovery in 2010, and it again reached the level of 2010 and the pre-crisis level only in 2014 . The data indicate that although manufacturing recovered from the crisis, it is not characterized by a considerable growth and it is not a process of reindustrialization taking place, but instead it is restructuring within manufacturing.

We consider the year 2009 as the base year in the detailed analysis of manufacturing since this was the lowest point of the crisis based on the reviewed national data. The number of employees in manufacturing increased by 16,000 persons to $2.5 \%$ between 2009 and 2014 at the national level (Table 1). In terms of employment numbers distinguishing the 13 subsections within manufacturing according to the revised Statistical classification of economic activities in the European Community (NACE Rev. 2.), the following subsections stand out: food products, beverages and tobacco products (CA),

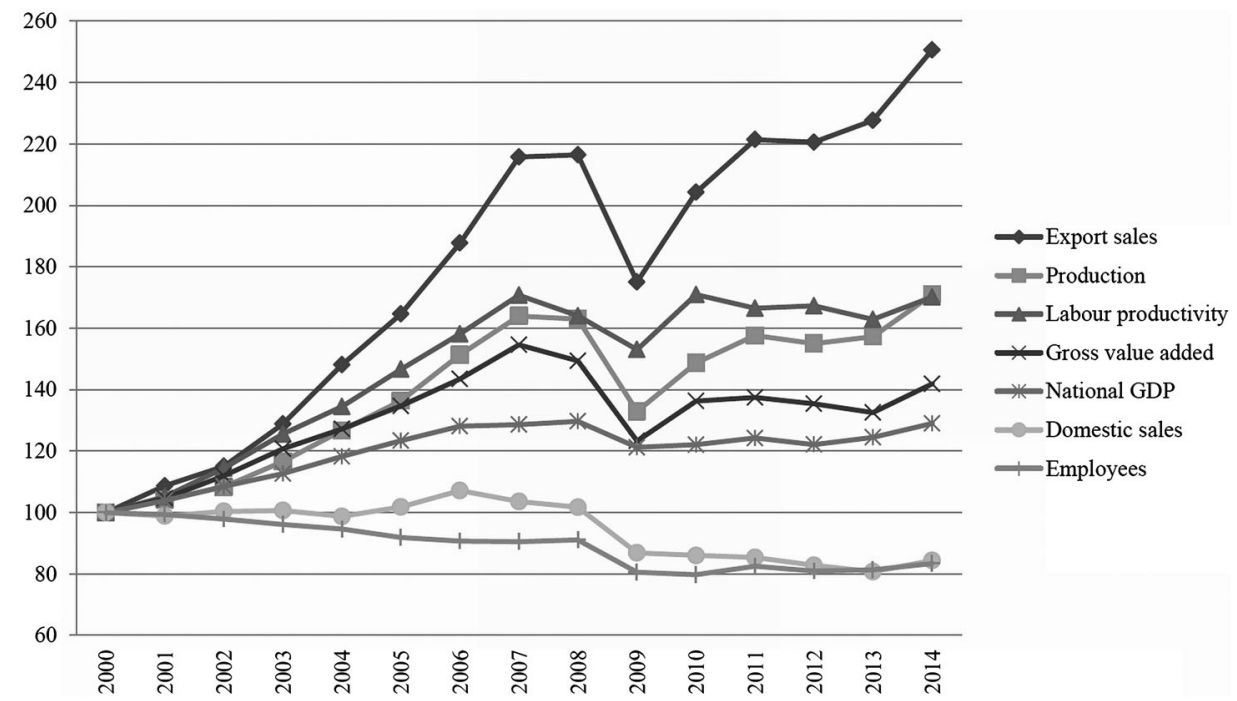

Figure 1. Change of the main indicators of manufacturing in Hungary, $2000=100 \%$. Source: HCSO STADAT database.

Note: The data for manufacturing export, production, labour productivity, domestic sales, GVA and GDP are in the volume index. 
Table 1. Number and distribution of manufacturing employment by subsection in Hungary.

\begin{tabular}{|c|c|c|c|c|c|c|}
\hline \multirow[b]{2}{*}{ Subsections } & \multirow[b]{2}{*}{ Code } & \multicolumn{3}{|c|}{$\begin{array}{c}\text { Number of employees } \\
\text { (thousands) }\end{array}$} & \multicolumn{2}{|c|}{$\begin{array}{l}\text { Distribution } \\
(\%)\end{array}$} \\
\hline & & 2009 & 2014 & Change & 2009 & 2014 \\
\hline Food products, beverages and tobacco products & CA & 102.9 & 102.7 & -0.2 & 15.8 & 15.4 \\
\hline Textiles, apparel, leather and related products & CB & 49.3 & 45.3 & -4.0 & 7.6 & 6.8 \\
\hline Wood and paper products, and printing & CC & 47.0 & 44.3 & -2.7 & 7.2 & 6.7 \\
\hline Coke, and refined petroleum products & $C D$ & 6.2 & 4.3 & -1.9 & 1.0 & 0.6 \\
\hline Chemicals and chemical products & $\mathrm{CE}$ & 13.4 & 15.0 & 1.6 & 2.1 & 2.3 \\
\hline Pharmaceuticals, medicinal chemical and botanical prod. & CF & 14.5 & 16.4 & 1.9 & 2.2 & 2.5 \\
\hline Rubber and plastic products, and other non-metallic products & CG & 66.4 & 67.3 & 0.9 & 10.2 & 10.1 \\
\hline $\begin{array}{l}\text { Basic metals and fabricated metal products, except machinery and } \\
\text { equipment }\end{array}$ & $\mathrm{CH}$ & 81.3 & 85.8 & 4.5 & 12.5 & 12.9 \\
\hline Computer, electronic and optical products & $\mathrm{Cl}$ & 53.3 & 42.8 & -10.5 & 8.2 & 6.4 \\
\hline Electrical equipment & $\mathrm{CJ}$ & 38.3 & 39.4 & 1.1 & 5.9 & 5.9 \\
\hline Machinery and equipment n.e.c. & CK & 52.8 & 58.9 & 6.1 & 8.1 & 8.9 \\
\hline Transport equipment & $\mathrm{CL}$ & 68.0 & 87.5 & 19.5 & 10.5 & 13.2 \\
\hline $\begin{array}{l}\text { Other manufacturing, and repair and installation of machinery and } \\
\text { equipment }\end{array}$ & $\mathrm{CM}$ & 55.8 & 55.4 & -0.4 & 8.6 & 8.3 \\
\hline Manufacturing & c & 649.3 & 665.1 & 15.8 & 100.0 & 100.0 \\
\hline
\end{tabular}

Note: Data based on the locations of companies employing over four people, n.e.c., not elsewhere classified. Source: HCSO County Statistical Yearbooks.

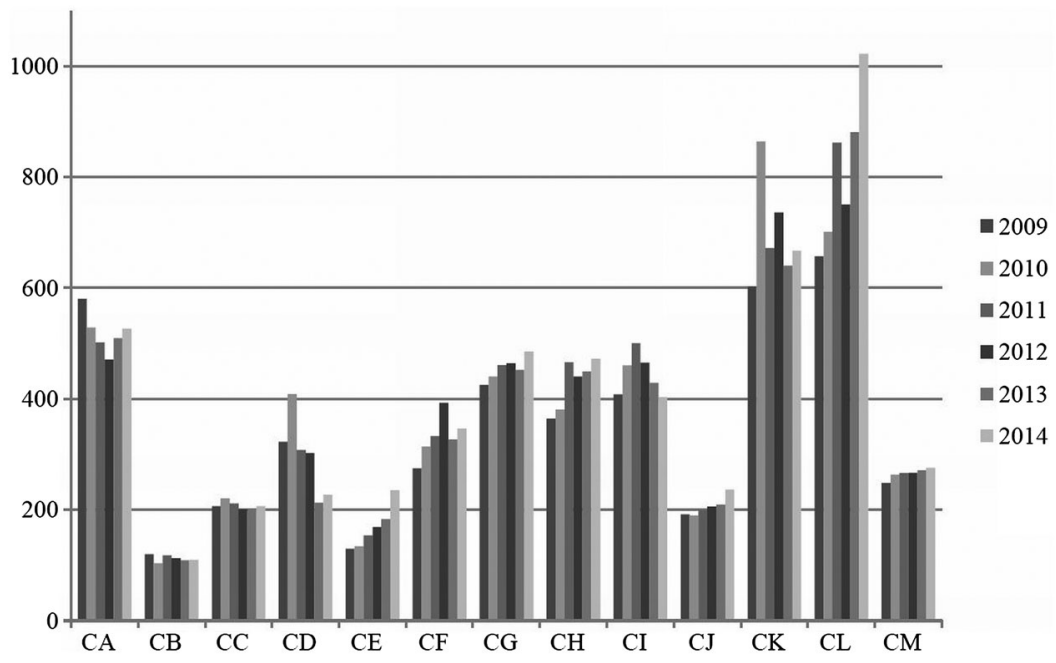

Figure 2. GVA of manufacturing subsections in Hungary at prices of 2009, billion HUF. Source: HCSO County Statistical Yearbooks.

Notes: Food products, beverages and tobacco products (CA); textiles, apparel, leather and related products (CB); wood and paper products, and printing (CC); coke, and refined petroleum products (CD); chemicals and chemical products (CE); pharmaceuticals, medicinal chemical and botanical products (CF); rubber and plastics products, and other non-metallic products (CG); basic metals and fabricated metal products, except machinery and equipment (CH); computer, electronic and optical products $(\mathrm{Cl})$; electrical equipment $(\mathrm{CJ})$; machinery and equipment n.e.c. (CK); transport equipment $(\mathrm{CL})$; other manufacturing, and repair and installation of machinery and equipment (CM); manufacturing (C).

transport equipment (CL), and basic metals and fabricated metal products $(\mathrm{CH})$. The number of employees increased in three subsections: transport equipment (CL) (with almost 20,000 persons), machinery and equipment not elsewhere classified (n.e.c.) (CK) and basic metals and fabricated metal products $(\mathrm{CH})$. Meanwhile there was a substantial decrease in the subsections of computer, electronic and optical products (CI), and textiles, 
apparel, leather and related products (CB). In the case of the remaining eight subsections, the employment numbers scarcely changed in the last six years.

In the period of 2009-2014, it was again the subsection of transport equipment (CL) which could considerably increase its share in the national GVA after a decline in 2012, from $14.5 \%$ to $19.6 \%$ (Figure 2). Furthermore, chemicals and chemical products (CE); pharmaceuticals, medicinal chemical and botanical products $(\mathrm{CF})$; and electrical equipment (CJ) were able to do so to a smaller extent. A more substantial decline can be observed in the subsections of computer, electronic and optical products (CI) and coke, and refined petroleum products (CD). There was no substantive change in proportion in the remaining subsections, even when considering the excessive values of certain years.

In Hungary, on the basis of employment numbers and GVA data, a dynamic reindustrialization process is hardly noticeable between 2009 and 2014; it is more of a change in the structure within manufacturing. Only the subsection of transport equipment strengthened its positions substantially and increased its employee numbers and GVA (Rechnitzer \& Smahó, 2012). The key question is whether there was spatial restructuring within the subsections. Is reindustrialization present in any regions, and if so, in which subsections?

\section{Methodology and data}

We manage the data of the capital and its own county, Pest County, collectively in the analysis of the reindustrialization of counties for practical purposes as they form one region in economic terms: $86 \%$ of the population of the Central Hungarian NUTS2 region, and $67 \%$ of the population of Pest County lives in the area of this metropolitan region (HCSO, 2015; Tóth, 2014). In Hungary, a total of 19 counties, that is, an additional 18 NUTS3-level regions besides Budapest and Pest County, are registered.

As we have reviewed, the spatial concentration of economic activities and the specialization of regions can equally contribute to the improvement of productivity. Several indicator systems have been elaborated to measure both concepts, generally identifying absolute and relative indicators within an indicator system (Bickenbach, Bode, \& Krieger-Boden, 2013; McCann, 2013). In our analysis, we adopted the analytical framework, concepts and method elaborated by Thissen et al. (2013) for analysing the specialization of EU regions:

- A subsection is characterized by spatial concentration if the companies operating in the subsection in question are typically concentrated in a few territorial units and if the spatial distribution of the subsection is different from what is expected based on the spatial distribution of the whole economy. We contrast spatial concentration with spatial dispersion (in the case of subsection). We use spatial dispersion to contrast with the concept (in the case of subsections).

- A territorial unit (county) is characterized by specialization if some subsections are prominently present, while others are only marginally present in the territorial unit and if the industry composition is different from the industry composition of the country. We contrast specialization with diversity (in the case of territorial units).

Thissen et al. (2013) used a Theil index to measure both the spatial concentration of subsections and the specialization of regions. The Theil index relies on the concept 
of entropy and measures the disorder of a studied criterion. In the case of Theil indexes, we use location quotients (LQ indexes) to measure the spatial concentration of economic activities and the specialization of regions. On the basis of the determined LQ values, we calculated two Theil indexes for each year between 2009 and 2014 (Thissen et al., 2013):

- a spatial concentration index for each manufacturing subsection $(I=19)$ :

$$
\text { Conc }_{j}=\left[\frac{1}{I} \frac{1}{\ln (I)}\right] \sum_{i=1}^{I}\left[\left(\frac{L Q_{i j}}{\frac{1}{I} \sum_{i=1}^{I} L Q_{i j}}\right) \cdot \ln \left(\frac{L Q_{i j}}{\frac{1}{I} \sum_{i=1}^{I} L Q_{i j}}\right)\right],
$$

- a specialization index for each county $(J=13)$ :

$$
\operatorname{Spec}_{i}=\left[\frac{1}{J} \frac{1}{\ln (J)}\right] \sum_{j=1}^{J}\left[\left(\frac{L Q_{i j}}{\frac{1}{J} \sum_{j=1}^{J} L Q_{i j}}\right) \cdot \ln \left(\frac{L Q_{i j}}{\frac{1}{J} \sum_{j=1}^{J} L Q_{i j}}\right)\right] .
$$

The values of these indexes close to 1 indicate the level of spatial concentration of a particular subsection and the specialization of the economy of a particular county. On the other hand, the values close to 0 signify dispersion (for the spatial concentration index) or diversity (for the specialization index).

We carried out two calculations for the concentration and specialization analyses, respectively: one based on the number of employees and the other based on export sales (county GVA data are not calculated by the Hungarian Central Statistical Office [HCSO] for subsections). Although the sales data are not directly related to the assessment of reindustrialization, they indicate the spatiality of the markets of the actors in the subsection, and the spatial effects of the dynamic growth of export sales demonstrated by Figure 1.

The following data are included in a particular county (Budapest and Pest County collectively), for a particular year (from 2009 to 2014), for a particular subsection (CA, ..., $\mathrm{CM})$ and for manufacturing $(\mathrm{C})$ :

- number of employees (for companies employing over four people) according to locations;

- amount of export sales (million Hungarian Forint [HUF], for companies employing over 49 people) according to locations.

On the basis of these initial data and the presented methodology, following the description of manufacturing in the counties, first we analyse the spatial concentration of the subsections and its temporal change, and then the specialization of the counties according to manufacturing subsections. 


\section{Manufacturing and its structure in the counties}

Based on the county locations data, the number of manufacturing employment increased by $2.9 \%$ at the national level, a rate which is below the $3.4 \%$ change in total employment number (Table 2). The growth was significant in four counties (in Györ-Moson-Sopron, Bács-Kiskun, Veszprém and Szabolcs-Szatmár-Bereg). Meanwhile, there was a decline in Budapest and its agglomeration (a decrease by 7\%), as well as in Zala and Komárom-Esztergom counties. If Budapest and Pest County are treated separately, then the findings show that the number of manufacturing employment decreased from 103,000 to 87,000 in Budapest, while it increased from 68,000 to 72,000 in Pest Country between 2009 and 2014. The number of manufacturing employment broadly stagnated in the remaining counties. It can be concluded that the number of manufacturing employment decreased at a much higher rate in the capital region compared to the total number of employees.

The proportion of manufacturing employment varies around the national average (20\%), across an interval of $12-37 \%$ in 2014 in the counties. The national average is significantly exceeded by four counties, Komárom-Esztergom, Vas, Fejér and GyörMoson-Sopron. The proportion of manufacturing employment is low in the capital region, and in Hajdú-Bihar, Baranya and Csongrád counties. In the capital region in line with the findings of Kiss (2007) and Kovács and Tosics (2014) - the importance

Table 2. Number of employees and its change by county in Hungary (1000 persons).

\begin{tabular}{|c|c|c|c|c|c|c|c|c|}
\hline \multirow[b]{3}{*}{ Counties } & \multicolumn{6}{|c|}{ Number of employee (thousands) } & \multirow{2}{*}{\multicolumn{2}{|c|}{$\begin{array}{l}\text { Change in the number } \\
\text { of employees, 2009- } \\
2014 \text { (thousands) }\end{array}$}} \\
\hline & \multicolumn{3}{|c|}{2009} & \multicolumn{3}{|c|}{2014} & & \\
\hline & Total & $\begin{array}{c}\text { Of total: } \\
\text { manufacturing }\end{array}$ & $\%$ & Total & $\begin{array}{c}\text { Of total: } \\
\text { manufacturing }\end{array}$ & $\%$ & Total & Manufacturing \\
\hline Bács-Kiskun & 142.0 & 35.0 & 24.6 & 150.8 & 40.3 & 26.7 & 8.8 & 5.3 \\
\hline Baranya & 110.3 & 19.6 & 17.8 & 110.2 & 19.4 & 17.6 & -0.1 & -0.2 \\
\hline Békés & 89.6 & 18.9 & 21.1 & 97.6 & 20.6 & 21.1 & 8.0 & 1.7 \\
\hline $\begin{array}{l}\text { Borsod-Abaúj- } \\
\text { Zemplén }\end{array}$ & 172.4 & 37.8 & 21.9 & 188.8 & 39.5 & 20.9 & 16.4 & 1.7 \\
\hline $\begin{array}{l}\text { Budapest and } \\
\text { Pest }\end{array}$ & 1294.9 & 171.7 & 13.3 & 1285.3 & 159.6 & 12.4 & -9.6 & -12.1 \\
\hline Csongrád & 122.1 & 22.6 & 18.5 & 124.9 & 22.5 & 18.0 & 2.8 & -0.1 \\
\hline Fejér & 131.8 & 45.3 & 34.4 & 140.2 & 46.8 & 33.4 & 8.4 & 1.5 \\
\hline $\begin{array}{l}\text { Győr-Moson- } \\
\text { Sopron }\end{array}$ & 145.2 & 40.9 & 28.1 & 164.8 & 51.5 & 31.3 & 19.6 & 10.6 \\
\hline Hajdú-Bihar & 150.5 & 27.5 & 18.3 & 157.5 & 25.6 & 16.3 & 7.0 & -1.9 \\
\hline Heves & 81.1 & 21.1 & 26.0 & 85.7 & 21.6 & 25.2 & 4.6 & 0.5 \\
\hline $\begin{array}{l}\text { Jász-Nagykun- } \\
\text { Szolnok }\end{array}$ & 102.1 & 28.5 & 27.9 & 108.9 & 29.8 & 27.4 & 6.8 & 1.3 \\
\hline $\begin{array}{l}\text { Komárom- } \\
\text { Esztergom }\end{array}$ & 104.2 & 40.3 & 38.7 & 101.0 & 37.9 & 37.5 & -3.2 & -2.4 \\
\hline Nógrád & 43.1 & 10.8 & 25.0 & 44.8 & 10.3 & 23.0 & 1.7 & -0.5 \\
\hline Somogy & 81.7 & 15.4 & 18.9 & 82.7 & 16.1 & 19.5 & 1.0 & 0.7 \\
\hline $\begin{array}{l}\text { Szabolcs- } \\
\text { Szatmár-Bereg }\end{array}$ & 133.5 & 28.1 & 21.0 & 152.2 & 31.9 & 21.0 & 18.7 & 3.8 \\
\hline Tolna & 58.5 & 11.1 & 19.0 & 62.8 & 13.0 & 20.7 & 4.3 & 1.9 \\
\hline Vas & 82.8 & 27.8 & 33.5 & 88.8 & 30.2 & 34.1 & 6.0 & 2.4 \\
\hline Veszprém & 96.7 & 24.8 & 25.7 & 104.5 & 29.1 & 27.8 & 7.8 & 4.3 \\
\hline Zala & 85.7 & 22.3 & 26.0 & 86.9 & 19.5 & 22.4 & 1.2 & -2.8 \\
\hline National & 3228.2 & 649.3 & 20.1 & 3338.4 & 668.0 & 20.0 & 110.2 & 18.7 \\
\hline
\end{tabular}

Note: Data for companies employing one and over one person, budgetary units and entities and designated non-profit organizations.

Source: HCSO County Statistical Yearbooks. 
of manufacturing becomes increasingly lower; the number of employees decreases and their proportion is also reduced. We can observe roughly similar tendencies in the counties with large public institutions (universities and health centres) (Baranya, Csongrád and Hajdú-Bihar).

The other measure of reindustrialization is the extent of and change in the share of manufacturing in county GVA (Figure 3). From 2009 to 2014, the share of manufacturing in county GVA increased considerably, by at least 6 percentage points, in seven counties (Jász-Nagykun-Szolnok, Borsod-Abaúj-Zemplén, Vas, Fejér, Győr-Moson-Sopron, BácsKiskun and Heves counties), but it decreased in three counties (Szabolcs-SzatmárBereg, Baranya and Zala counties). In 2014, the national average of $23.3 \%$ was significantly exceeded by four counties, which are above $40 \%$ (Komárom-Esztergom, Győr-MosonSopron, Fejér and Vas counties). On the other hand, this share is well below the national average in Tolna (14.4\%), Baranya (15.0\%) counties and the region of Budapest (15\%). Evidently, the tendency of the share depends not only on manufacturing, but also on the change in the performance of the other sectors of the region.

The presented data indicate that manufacturing is continuously losing its position in the only metropolitan region of Hungary, in Budapest and its agglomeration. However, this region is still the manufacturing centre of the country: $26.4 \%$ of the manufacturing employees of the country worked in Budapest and Pest County in 2009, while this proportion was $23.9 \%$ in 2014 ; it also has a high share in national manufacturing GVA, but it decreased from $32.2 \%$ to $31.0 \%$.

In terms of reindustrialization, the data of the last years imply complex spatial processes. Reindustrialization, that is, the increase in the number of manufacturing employment and GVA, can be observed in some counties, such as Györ-Moson-Sopron,

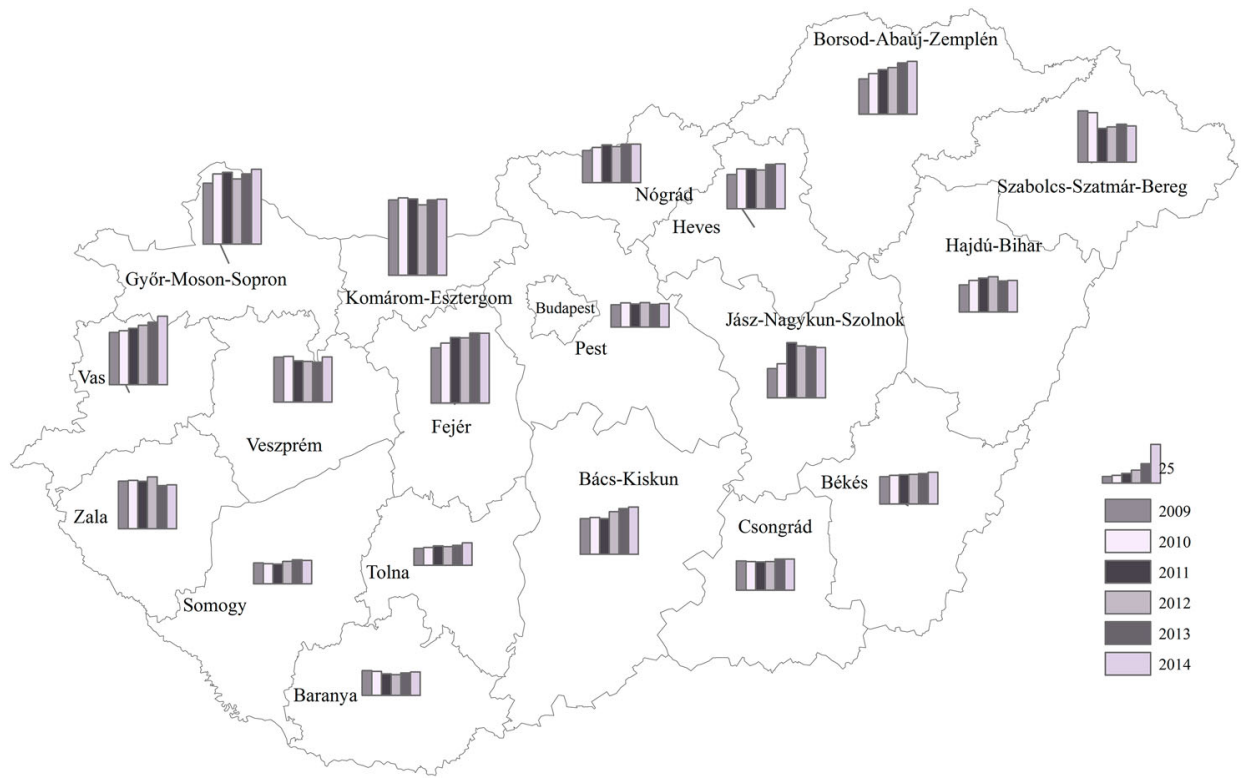

Figure 3. Share of manufacturing GVA in the counties of Hungary, 2009-2014, (\%). Source: HCSO County Statistical Yearbooks. 
Komárom-Esztergom, Vas and Bács-Kiskun counties, in addition to Borsod-AbaújZemplén. Meanwhile, manufacturing declined in several regions; that is, deindustrialization is in progress in the capital and its agglomeration, as well as in rural university knowledge centres in Baranya, Hajdú-Bihar and Csongrád counties.

The question is whether the reindustrializing regions are characterized by the spatial concentration of subsections and the specialization of counties. Are there cross-county border macro-regional concentrations in development which can facilitate the clustering of industries and thereby the advancing of reindustrialization?

\section{Spatial concentration of manufacturing subsections and specialization of counties}

The concentration-related Theil indexes calculated based on the employment number of manufacturing subsections scarcely changed between 2009 and 2014 (Figure 4). The obtained values are relatively low and vary across a small range, which indicates that the activities categorized in the subsections are performed in relatively many counties. At the same time, the low index-values refer to the excessive role of the capital region; in terms of the absolute number, the capital is the most populated in each manufacturing subsection. The employees of several subsections are concentrated here, for example, $66 \%$ of the employees in pharmaceuticals, medicinal chemical and botanical products (CF); the share of the capital region in coke, and refined petroleum products (CD) is $50 \%$; in wood and paper products, and printing (CC) it is $35 \%$, while the lowest share is in transport equipment (CL) with $12 \%$.

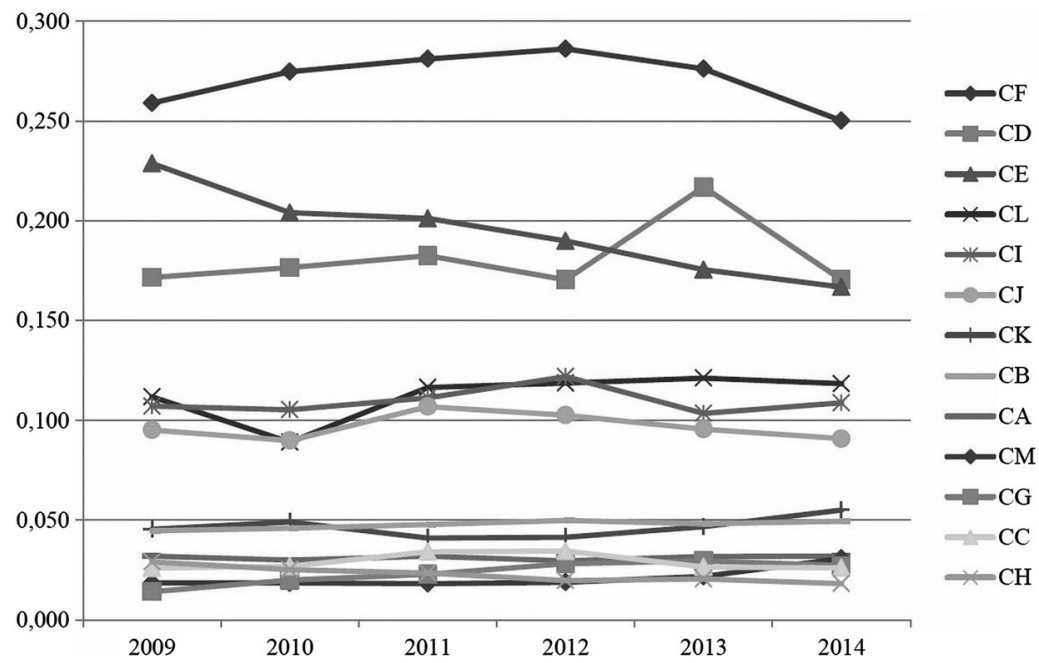

Figure 4. Concentration Theil indexes calculated based on employment numbers in Hungary. Source: HCSO STADAT database.

Notes: Food products, beverages and tobacco products (CA); textiles, apparel, leather and related products (CB); wood and paper products, and printing (CC); coke, and refined petroleum products (CD); chemicals and chemical products (CE); pharmaceuticals, medicinal chemical and botanical products (CF); rubber and plastics products, and other non-metallic products (CG); basic metals and fabricated metal products, except machinery and equipment (CH); computer, electronic and optical products $(\mathrm{Cl})$; electrical equipment $(\mathrm{CJ})$; machinery and equipment n.e.c. (CK); transport equipment $(\mathrm{CL})$; other manufacturing, and repair and installation of machinery and equipment (CM); manufacturing (C). 
Three subsections are spatially strongly concentrated (CF, CD and CE), and these employ relatively few people at both the regional and national levels. CL, CI and CJ subsections are weakly concentrated, and their employment numbers and export sales are both relatively high. Two of them are the past (CI) and present (CL) major key subsections of domestic manufacturing. The remaining seven subsections can be regarded as spatially dispersed, with low concentration values.

The employees of the three subsections which are spatially strongly concentrated according to the Theil-index (CF, CD and CE) work in only one or two counties. The spatially weakly concentrated subsections (CL, CI and CJ) occur everywhere, but they are typically present with higher employment numbers only in three or four counties. Only transport equipment (CL) is characterized by a significant change, and while the subsection had an outstanding number in three counties in 2009 (Györ-Moson-Sopron, Fejér and Komárom-Esztergom counties), it applied to only one county in 2014. This county is Györ-Moson-Sopron, where the number of employees in transport equipment increased from 12,100 persons to 21,700 persons from 2009 to 2014. Every fourth Hungarian transport equipment manufacture worker is employed in this county. The most dispersed subsections ( $\mathrm{CH}, \mathrm{CC}$ and $\mathrm{CG}$ ) are almost evenly located spatially.

The concentration Theil indexes calculated based on export sales data show much stronger spatial concentration compared to the foregoing (we considered the data of companies employing over 49 people according to locations). Similarly to the employment Theil indexes, the spatial concentration is strong in the same three subsections (CD, CF and $\mathrm{CE}$ ). The exporting companies of these subsections are concentrated almost only in one particular county: coke, and refined petroleum products (CD) and pharmaceuticals, medicinal chemical and botanical products (CF) are concentrated in the capital region, while chemicals and chemical products (CE) are concentrated in Borsod-AbaújZemplén County. Three further subsections are moderately concentrated (CI, CC and $\mathrm{CB}$ ), while the spatial concentration of the remaining seven subsections measured based on export data can be considered low and stable throughout.

The Theil indexes related to county specialization calculated based on the employment number of manufacturing subsections remain in a narrow range in the studied period (Figure 5). Three counties can be defined as specialized: Györ-Moson-Sopron, Somogy and Tolna. Moderately specialized counties are Borsod-Abaúj-Zemplén, Veszprém and Heves. The counties considered as diverse are Komárom-Esztergom and Vas counties, as well as the manufacturing of the capital region.

The county specialization Theil indexes calculated based on the export sales data are in a broader range and show higher values in the studied period compared to the foregoing. The specialization of Tolna, Somogy and Borsod-Abaúj-Zemplén counties stands out. The manufacturing of the capital region and Komárom-Esztergom, Veszprém and Békés counties can be defined as diverse. Somogy and Heves counties became more specialized during the studied period, while the manufacturing of Zala, Jász-Nagykun-Szolnok and Komárom-Esztergom counties became more diverse.

The spatial concentrations of each manufacturing subsection and the specialization of the regions partially prognosticate the possibilities of reindustrialization. Nevertheless, the structural change of the counties is influenced not only by the current situation of manufacturing, but also by the development level of regions (which determines the potential 


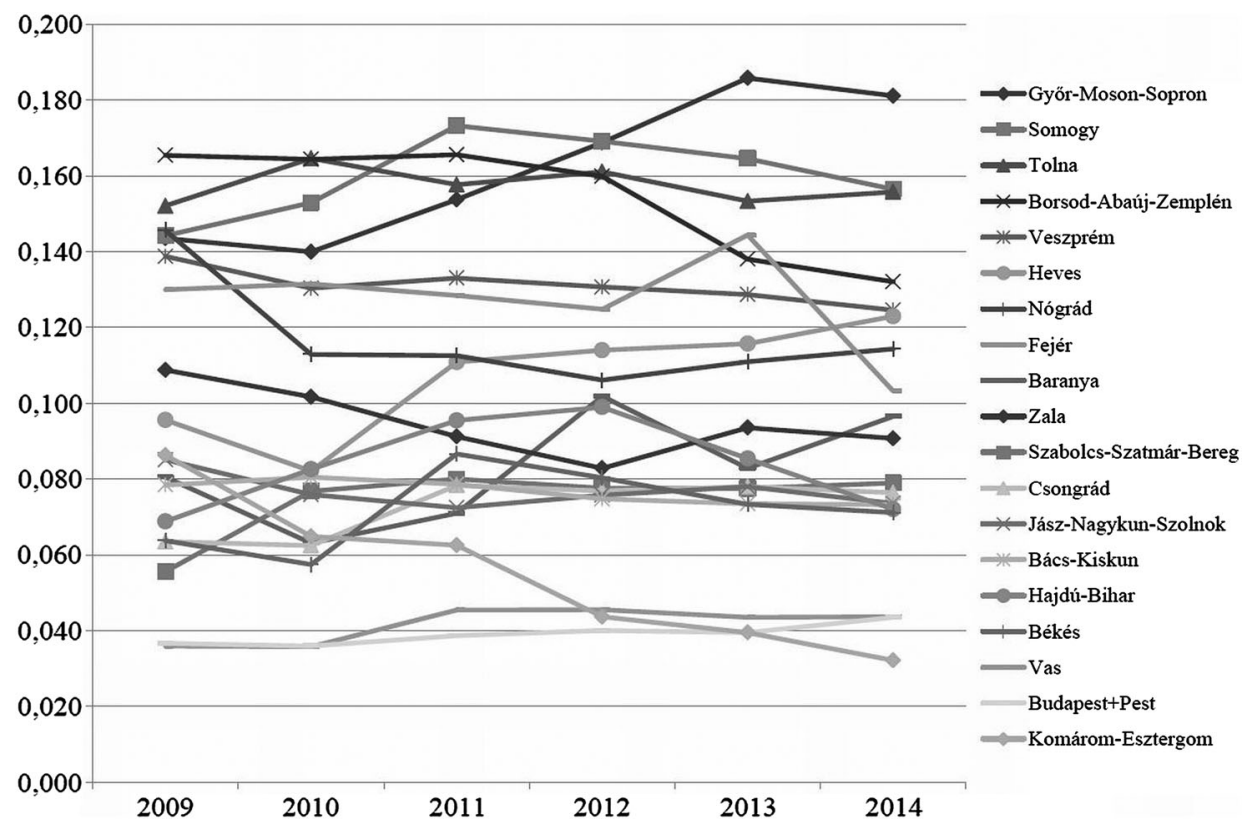

Figure 5. Theil indexes calculated based on employment data for the manufacturing specialization of counties in Hungary. Source: HCSO County Statistical Yearbooks.

competitive advantages) and by the size of the labour market (as agglomeration economies) and its specificities (employment and unemployment rates).

\section{The questions related to the spatiality of reindustrialization}

The question arises, given the reviewed data and processes, whether it is a realistic government objective that the share of industry should reach $30 \%$ in gross domestic product in Hungary. On the basis of international comparisons, the target of $30 \%$ seems too bold but not unrealistic if we look at the industry as a whole. Questions and doubts arise when we assess the spatial possibilities and limitations of reindustrialization.

According to the reviewed basic indicators, reindustrialization shows a rather mixed picture in Hungary in spatial terms. The rate of manufacturing is high and increasing in several counties, and stagnating or decreasing in others. Although the economic structure of the counties has been changing over a longer period, we still think that based on the specificities and the presented data from 2009, and by comparing the counties' performance to the national values, the types of counties can be defined in terms of reindustrialization (Figure 6):

(a) Reindustrialized counties, where the proportion of manufacturing employment is at least $30 \%$ (20\% at the national level), and the share of GVA is above $40 \%$ (22.8\% at the national level), labour productivity and export are high: Komárom-Esztergom, GyörMoson-Sopron, Fejér and Vas counties (with a total population of 1.4 million).

(b) Reindustrializing counties, where the number of manufacturing employment and/or the share of GVA is increasing, labour productivity generally is improving and export 


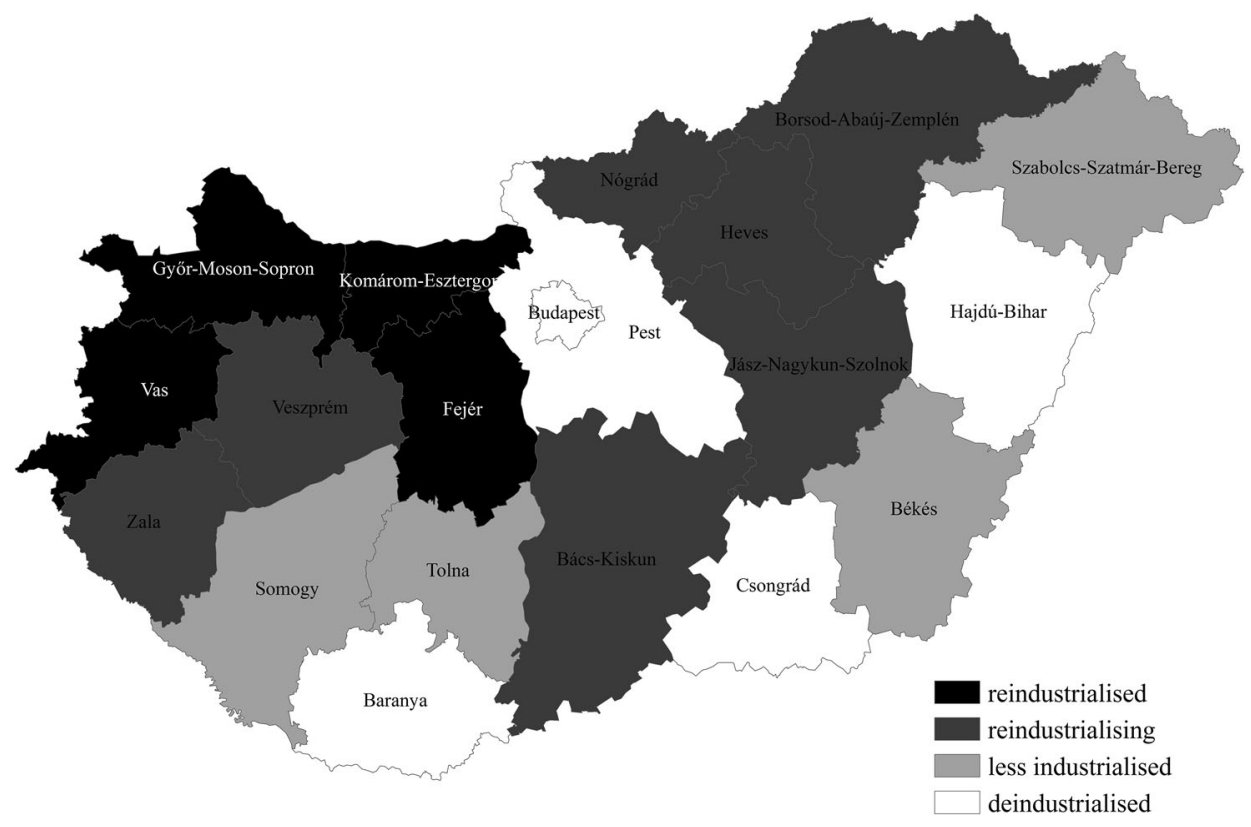

Figure 6. Counties of Hungary in terms of reindustrialization. Source: Own construction.

is above the national average: Jász-Nagykun-Szolnok, Bács-Kiskun, Borsod-AbaújZemplén, Heves and Nógrád, in addition to Veszprém and Zala counties (with a total population of 2.7 million).

(c) Less industrialized counties, where there are certain indications of reindustrialization but both basic indexes are around the national average, and labour productivity and export are both low: Békés, Szabolcs-Szatmár-Bereg, Somogy and Tolna counties (with a total population of 1.5 million).

(d) Deindustrialized counties, where the number of manufacturing employment and/or the share of GVA is decreasing, and domestic sales is relatively high: the capital region (Budapest and Pest county collectively), Baranya, Csongrád and Hajdú-Bihar counties (with a total population of 4.3 million).

The above-described types have different possibilities in terms of reindustrialization. Based on our review of the literature, these possibilities are limited by the spatial external economies of scale (agglomeration economies), the phases of competitive development in line with the development level of the counties (and the region types according to smart specialization), as well as the labour market conditions (Table 3).

In the reindustrialized counties as in industrial production zones, there are cities whose institutional background and labour market are scarce, and unemployment rate is low (3$4 \%$, except for one county, Fejér, where it is $6.6 \%$ ). In terms of competitive advantages, these regions are efficiency-driven and follower types (GDP per capita is around twothirds of the EU28 average and economic growth is excessive from 2009), where the conditions of high-tech manufacturing activities are given. The GVA may increase, but the number of employees is not expected to grow. If a manufacturing subsection grows in 
Table 3. The main indicators of the economy of counties in Hungary.

\begin{tabular}{|c|c|c|c|c|c|c|c|c|c|}
\hline \multirow[b]{2}{*}{ Counties } & \multicolumn{3}{|c|}{$\begin{array}{l}\text { GDP per inhabitant, PPS } \\
\text { (EU28=100\%) }\end{array}$} & \multicolumn{3}{|c|}{ Employment rate (\%) } & \multicolumn{3}{|c|}{ Unemployment rate (\%) } \\
\hline & 2009 & 2014 & Change & 2009 & 2014 & Change & 2009 & 2014 & Change \\
\hline Bács-Kiskun & 42.6 & 50.8 & 8.1 & 46.8 & 52.0 & 5.2 & 10.9 & 9.6 & -1.3 \\
\hline Baranya & 44.5 & 43.5 & -1.0 & 46.3 & 50.7 & 4.4 & 11.4 & 8.4 & -2.9 \\
\hline Békés & 36.2 & 39.6 & 3.4 & 44.2 & 49.3 & 5.2 & 13.6 & 10.4 & -3.2 \\
\hline Borsod-Abaúj-Zemplén & 39.5 & 44.0 & 4.5 & 41.9 & 47.8 & 6.0 & 16.0 & 11.3 & -4.7 \\
\hline Budapest and Pest & 108.1 & 107.6 & -0.5 & 54.4 & 57.7 & 3.3 & 6.5 & 6.2 & -0.3 \\
\hline Csongrád & 48.1 & 50.4 & 2.3 & 48.9 & 54.3 & 5.5 & 7.7 & 7.0 & -0.8 \\
\hline Fejér & 54.7 & 66.1 & 11.3 & 50.7 & 56.3 & 5.7 & 9.1 & 6.6 & -2.5 \\
\hline Győr-Moson-Sopron & 70.0 & 84.8 & 14.8 & 53.9 & 59.3 & 5.3 & 6.5 & 3.0 & -3.5 \\
\hline Hajdú-Bihar & 47.5 & 48.9 & 1.4 & 42.7 & 50.3 & 7.6 & 11.7 & 12.9 & 1.2 \\
\hline Heves & 45.1 & 47.4 & 2.3 & 44.4 & 50.3 & 5.9 & 13.3 & 9.8 & -3.5 \\
\hline Jász-Nagykun-Szolnok & 43.7 & 43.5 & -0.2 & 46.6 & 54.2 & 7.6 & 11.3 & 7.6 & -3.7 \\
\hline Komárom-Esztergom & 63.8 & 67.5 & 3.7 & 52.5 & 56.6 & 4.2 & 8.2 & 4.3 & -3.9 \\
\hline Nógrád & 29.5 & 29.8 & 0.3 & 42.3 & 49.1 & 6.8 & 15.7 & 8.4 & -7.3 \\
\hline Somogy & 40.7 & 42.3 & 1.6 & 43.6 & 49.3 & 5.7 & 12.3 & 8.9 & -3.4 \\
\hline Szabolcs-Szatmár-Bereg & 34.8 & 37.0 & 2.1 & 40.8 & 49.6 & 8.8 & 18.5 & 13.6 & -4.9 \\
\hline Tolna & 48.7 & 51.9 & 3.2 & 47.4 & 53.8 & 6.4 & 9.4 & 5.4 & -4.0 \\
\hline Vas & 53.6 & 68.7 & 15.0 & 51.0 & 58.6 & 7.6 & 10.3 & 3.6 & -6.6 \\
\hline Veszprém & 44.5 & 50.4 & 5.8 & 49.4 & 56.3 & 6.9 & 10.1 & 5.3 & -4.8 \\
\hline Zala & 52.6 & 51.4 & -1.2 & 51.7 & 54.4 & 2.7 & 10.8 & 8.1 & -2.7 \\
\hline National & 64.5 & 68.0 & 3.5 & 48.8 & 54.1 & 5.3 & 10.0 & 7.7 & -2.3 \\
\hline
\end{tabular}

Source: HCSO STADAT database.

these regions, it can do so only at the expense of other subsections as migration within the country is moderate. Győr-Moson-Sopron is the only county benefiting from specialization (from the clustering of transport equipment production); the manufacturing of the other counties is more dispersed.

The majority of the regions of reindustrializing counties are also city regions which qualify as potential industrial production zones with industrial traditions, but with scarce institutional background (except for two regions, Miskolc and Veszprém, which have higher educational training in engineering) and a high unemployment rate (8$11 \%$, except for Veszprém with 5.3\%). In terms of competitive development, these regions are factor-driven and less advanced (GDP per capita is around $40-50 \%$ of the EU28 average, except for Nógrád, with 30\%). Low-tech manufacturing is expected to strengthen here, and modern manufacturing is expected to grow in the city regions with higher educational training in engineering. The majority of the counties is relatively specialized, whose exploitation may entail additional advantages.

Most of the less industrialized counties are also city regions, which are factor-driven (and non-S\&T-driven regions) and less advanced (GDP per capita is around $40-50 \%$ of the EU28 average), and with a high unemployment rate (9-14\%, except for Tolna County, with 5.4\%). Low-tech (labour-intensive) manufacturing is expected to grow, especially food production. The manufacturing of Somogy and Tolna counties is specialized, but these counties do not reach the critical threshold due to low absolute numbers.

In the capital region, as well as in the large rural university regions, deindustrialization is in progress, manufacturing is sidelined and services are gaining focus. The capital is in an innovation-driven phase; it is a typical knowledge region, where there is a chance of developing synergies between various service businesses (urbanization agglomeration economies) and strengthening the business services related to rural manufacturing. The 
rural university cities (Debrecen, Pécs and Szeged) are efficiency-driven, follower-type potential knowledge regions, where primarily the research-intensive industries can grow (e.g. pharmaceuticals) as higher educational training in engineering is rather moderate in every large university. The economic growth of these regions is below the EU average; moreover, the growth of Baranya County and the capital is very slow, and the latter holds back national growth, in our opinion.

\section{Conclusions}

In our paper, we have reviewed the possibilities of reindustrialization in the context of manufacturing through the example of Hungary, a post-socialist economy of the EU, by looking at the tendency of relevant indicators such as the number of employees, value added and labour productivity. The data reveal that reindustrialization is hardly perceivable until 2014 at the level of the national economy. Although manufacturing export and the value of production increased after the lowest point of 2009, the number of employees, GVA and labour productivity changed only to a small extent. However, the subsections are characterized by certain restructuring.

There was a minimal change in the distribution of manufacturing and its subsections by county after 2009, and the concentration and specialization Theil indexes changed to only a small extent. The share of manufacturing in the GVA increased in several counties between 2009 and 2014; that is, a certain extent of reindustrialization is present here. The number of manufacturing employment changed less in the majority of the counties, and slightly increased or decreased only to a small extent.

It is conspicuous that in the capital region (Budapest and Pest County), the number of manufacturing employees decreased by 12,100 persons, with their proportion within the region changing from $13.3 \%$ to $12.4 \%$, while the share of manufacturing in GVA did not change essentially. Consequently, the capital and its agglomeration are characterized by a deindustrialization process in line with the international experience: in cities, services and the related creative industries are growing, while the low-tech and high-tech manufacturing is found in rural city regions. As every county seat can be accessed in about one or one and one-half hours from Budapest by road (especially by motorway), and the majority of modern business services can be arranged by ICT devices, the service sector of the capital provides for the entire country in several activities achieving economies of scale. Thus, based on the capital-provinces division of labour, the modern business services utilizing urbanization agglomeration economies have realistic advancement opportunities in the capital and its agglomeration, while the manufacturing built on localization agglomeration economies have a chance to develop in the rural city regions.

In our opinion, reindustrialization is possible in the less developed counties, where closed-down manufacturing companies operated in the socialist era. It is practical to variously incorporate reindustrialization in the programmes related to the smart specialization of less developed city regions, funded by the EU in the period of 2014-2020, of course in addition to other activities whose competitive advantages are perceivable.

The above-mentioned 4th industrial revolution is expected to rearrange the international division of labour and the centre-periphery relations, which is already happening today, for example, in the reindustrialization of post-socialist countries. Manufacturing activities are forced out of developed countries, transferred to the (almost) periphery, 
while high value-added state-of-the-art technology and the services in its service are growing in the centre. It is concerning that the reindustrialization generated in this way is experienced by the less advanced post-socialist countries as a dynamic development, even though it is exactly what preserves their fallback. Reindustrialization might be temporarily needed in the less advanced city regions of these countries, but at the same time the factors of knowledge-based development should be created, especially the areas of training and the strengthening of entrepreneurship.

\section{Disclosure statement}

No potential conflict of interest was reported by the authors.

\section{References}

Ács, J. Z., \& Varga, A. (2002). Geography, endogenous growth, and innovation. International Regional Science Review, 25(1), 132-148. doi:10.1177/016001702762039484

Barta, G. (2002). A magyar ipar területi folyamatai, 1945-2000 [The regional processes of Hungarian industry, 1945-2000]. Budapest-Pécs: Dialóg Campus.

Barta, G., Czirfusz, M., \& Kukely, G. (2008). Re-industrialization in the world and in Hungary. European Spatial Research and Policy, 15(2), 5-26.

Bickenbach, F., Bode, E., \& Krieger-Boden, C. (2013). Closing the gap between absolute and relative measures of localization, concentration or specialization. Papers in Regional Science, 92, 465-479. doi:10.1111/j.1435-5957.2012.00460.x

Brakman, S., Garretsen, H., \& van Marrewijk, C. (2009). The new introduction to geographical economics. Cambridge: Cambridge University Press.

Cairncross, A. (1982). What is deindustrialisation? In F. Blackaby (Ed.), Deindustrialisation (pp. 517). London: Pergamon Press.

Camagni, R. (2002). On the concept of territorial competitiveness: Sound or misleading? Urban Studies, 13, 2395-2411. doi:10.1080/0042098022000027022

Capello, R. (2015). Regional economics. London: Routledge.

Christopherson, S., Martin, R., Sunley, P., \& Tyler, P. (2014). Reindustrialising regions: Rebuilding the manufacturing economy. Economy and Society, 7, 351-358.

Cimoli, M., Dosi, G., \& Stiglitz, J. E. (2015). The rationale for industrial and innovation policy. Intereconomics, 3, 126-132.

Combes, P., Mayer, T., \& Thisse, J.-J. (2008). Economic geography. The integration of regions and nations. Princeton, NJ: University Press.

Drucker, J. (2013). Industrial structure and the source of agglomeration economies: Evidence from manufacturing plant production. Growth and Change, 44, 54-91. doi:10.1111/grow.12002

Etzioni, A. (1983). Reindustrialization of America. Review of Policy Research, 2, 677-694. doi:10. 1111/j.1541-1338.1983.tb00797.x

European Commission. (2010). An integrated industrial policy for the globalisation era. Putting Competitiveness and Sustainabilityat Centre Stage. COM (2010) 614. final, Brussels.

European Commission. (2012). Guide to research and innovation strategies for smart specialisations (RIS 3). Luxembourg.

European Commission. (2014). For a European industrial renaissance. COM (2014) 14. Final, Brussels.

European Union. (2015). EU structural change 2015. Brussels: Author (DOI 10.2873/64651).

Foray, D. (2015). Smart specialization: Opportunities and challenges for regional innovation policy. London: Routledge.

Fujita, M., Krugman, P., \& Venables, A. J. (1999). The spatial economy. Cities, regions and international trade. Cambridge, MA: MIT Press. 
Fujita, M., \& Thisse, J.-F. (2002). Economics of agglomeration. Cities, industrial location, and regional growth. Cambridge, MA: Cambridge University Press.

Hungarian Central Statistical Office. (2015). Territorial statistical yearbook. Budapest: Author.

Johansson, B. (2000). Regional competition: Endogenous and policy-supported processes. In P. Batey \& P. Friedrich (Eds.), Regional competition (pp. 34-65). Berlin: Springer.

Kiss, É. (2007). Foreign direct investment in Hungary: Industry and its spatial effects. Eastern European Economics, 45(1), 6-28. doi:10.2753/EEE0012-8775450101

Kiss, É. (2012). The impacts of the economic crisis on the spatial organization of Hungarian industry. European Urban and Regional Studies, 19(1), 62-76. doi:10.1177/0969776411428652

Kovács, Z., \& Tosics, I. (2014). Urban sprawl on the Danube. The impacts of suburbanization in Budapest. In K. Stanilov \& L. Sykora (Eds.), Confronting suburbanization. Urban decentralization in postsocialist central and Eastern Europe (pp. 5-17). Chichester: John Wiley \& Sons.

Krugman, P. (1988). Deindustrialization, reindustrialization, and the real exchange rate (NBER Working Paper Series, 2586). Cambridge, MA: National Bureau of Economic Research.

Kudina, A., \& Pitelis, C. (2014). De-industrialisation, comparative economic performance and FDI inflows in emerging economies. International Business Review, 23, 887-896. doi:10.1016/j. ibusrev.2014.02.001

Landesman, M. A. (2015). Industrial policy: Its role in the European economy. Intereconomics, 3, 133-138.

Lengyel, I. (2014). Reorganizing of Hungarian manufacturing sector: Impacts of EU accession and global crises. European Journal of Business Research, 14, 93-100. doi:10.18374/EJBR-14-2.11

Lorentzen, A. (1999). Industrial development, technology change, and regional disparity in Hungary. European Planning Studies, 7, 463-482. doi:10.1080/09654319908720530

Lower, M. D. (1982). The reindustrialization of America. Journal of Economic Issues, 16, 629-636. doi:10.1080/00213624.1982.11504023

Lux, G. (2015). The institutional conditions of reindustrialization on post-crisis central Europe. Journal of Economics and Management, 19, 1, 16-33.

McCann, P. (2013). Modern urban and regional economics. Oxford: Oxford University Press.

McCann, P. (2015). The regional and urban policy of the European Union. Cohesion, results-orientation and smart specialisation. Cheltenham: Edward Elgar.

Nemes Nagy, J. (2000). The new regional structure in Hungary. In G. Gorzelak, G. Maier, \& G. Petrakos (Eds.), Integration and transition in Europe: The economic geography of interaction (pp. 170-186). London: Routledge.

Organisation for Economic Co-operation and Development. (2013). Innovation-driven growth in regions: The role of smart specialisation (preliminary version). Paris: Author.

Porter, M., \& Heppelman, J. (2015). How smart, connected products are transforming companies. Harvard Business Review, 10, 97-114.

Porter, M. E. (1990). The competitive advantage of nations. New York, NY: The Free Press.

Rechnitzer, J., \& Smahó, M. (Eds.). (2012). Vehicle industry and competitiveness of regions in central and Eastern Europe. Győr: Universitas-Győr Nonprofit.

Schwab, K. (2015). The fourth industrial revolution. Foreign Affairs. Retrieved from https://www. foreignaffairs.com/articles/2015-12-12/fourth-industrial-revolution

Scott, A., \& Storper, M. (Eds.). (1992). Pathways to industrialization and regional development. London: Routledge.

Seravalli, G. (2015). An introduction to place-based development economics and policy. Heidelberg: Springer.

Stimson, R. J., Stough, R. R., \& Roberts, B. H. (2006). Regional economic development. Analysis and planning strategy. Berlin: Springer.

Szirmai, A. (2012). Industrialisation as an engine of growth in developing countries, 1950-2005. Structural Change and Economic Dynamics, 4, 406-420. doi:10.1016/j.strueco.2011.01.005

Thissen, M., van Oort, F., Diodato, D., \& Ruijs, A. (2013). Regional competitiveness and smart specialization in Europe. Cheltenham: Edward Elgar.

Tóth, G. (2014). Az agglomerációk, településegyüttesek lehatárolásának eredményei [Demarcation results of agglomerations and settlement groups]. Területi Statisztika, 54(3), 289-300. 
Tregenna, F. (2009). Characterising deindustrialisation: An analysis of changes in manufacturing employment and output internationally. Cambridge Journal of Economics, 3, 433-466. doi:10. 1093/cje/ben032

Tregenna, F. (2013). Deindustrialization and reindustrialization. In A. Szirmai, W. Naudé, \& L. Alcorta (Eds.), Pathways to industrialization in the twenty-first century (pp. 76-101). Oxford: Oxford University Press.

Weiss, J. (2002). Industrialisation and globalisation. Theory and evidence from developing countries. London: Routledge.

Westkamper, E. (2014). Towards the re-industrialization of Europe: A concept for manufacturing for 2030. Heidelberg: Springer.

Wink, R., Kirchner, L., Koch, F., \& Speda, D. (2015). There are many roads to reindustrialization and resilience: Place-based approaches in three German urban regions. European Planning Studies, doi:10.1080/09654313.2015.1046370 